\title{
The Impact of a Digital Influencer to the Purchase Decision
}

\author{
Maria Francisca Lies Ambarwati ${ }^{1}$, Herlina Damaryanti ${ }^{1}$, Harjanto Prabowo ${ }^{2}$, and Muhammad Hamsal ${ }^{2}$
}

\begin{abstract}
Electronic word of mouth (eWOM) nowadays has been one among the many marketing tools which has given a wide range and easy accessibility. One kind of eWOM is digital influencer who uses the social media platforms such as YouTube, Instagram, Facebook. The digital influencer has a role as a communicator who influences the purchase decision of the viewers. The purpose of this study is to investigate the impact of a beauty vlogger to the purchase intention of the viewers in the YouTube channel. This study uses quantitative research method with analysis techniques include tests of validity, reliability, normality, linearity, simple linear regression, statistic descriptive, and determination. Data analysis was defined by the total quota sampling technique. Data collection was done by distributing questionnaires to 100 respondents who were the viewers of the YouTube video blog. The result of this study shows that the contribution of the digital influencer to the decision of purchasing cosmetic products is $87.6 \%$. This result opens the opportunity to producers of life-style products to collaborate with the beauty vloggers to advertise their products.
\end{abstract}

Keywords-Electronic Word of Mouth, YouTube, Beauty Vlogger, Purchase Intention.

\section{INTRODUCTION}

Every organization needs to communicate with their stakeholders. In business, such activity is also known as Marketing communication. Chris Fill and Barbara Jamieson [1] mention that marketing communications provides a core activity so that all interested parties can understand the intentions of others and appreciate the value of the goods and services offered. As what Kotler \& Armstrong (2012) claim that consumers make purchase decisions every day, producers need to be creative in reaching their target customers. Since companies now have a harder time reaching out to consumers, they use internet to communicate with their customers. During recent years, a new type of social factor has emerged, claimed to influence consumers more than before[2]. This social factor is what we today call as the social media [3]. The rapid development of technology in this digital era makes consumers become easier to access the internet. Information dissemination is now using Internet-based media or online media. Along with these developments, there are also platforms in online social media that are

\footnotetext{
${ }^{1}$ Maria Francisca Lies Ambarwati and Herlina Damaryanti are with STIKS Tarakanita, Jakarta, 13450, Indonesia. Email: maria_fl_ambarwati@yahoo.com; hdamaryanti@gmail.com.

${ }^{2}$ Harjanto Prabowo and Muhammad Hamsal are with Binus University, Jakarta 11480, Indonesia. Email: harprabowo@binus.edu; mhamsal@binus.edu.
}

useful as a means of sharing such as Facebook, Twitter, Instagram, YouTube, etcetera.

The content that people upload to the social media has various types such as audio, photos, and even videos. One among those things that is currently used is a video blog or often called a vlog. Vlogs can usually be found on YouTube. Product reviews made by beauty vlogger are usually used by consumers as a consideration in buying products. By looking at product reviews, consumers can make judgments about whether the product they want to buy is a good product or not so they will not feel loss later. Beauty vlogger is a medium for creating electronic word of mouth (EWOM) communication through videos that they upload to YouTube, where electronic word of mouth is a form of marketing communication that contains positive or negative statements made by potential customers, customers and former customers about a product or company, available to many people or institutions through the internet[4]. Because of this increase in popularity and usage, the authors have investigated how millennial attitudes are affected by this promotional message.

\section{LITERATURE REVIEW}

\section{A. Electronic Word of Mouth}

Kotler \& Keller [5] stated that Marketing communications are the means by which firms attempt to inform, persuade, and remind consumers either directly or indirectly about the products and brands they sell. One among the many tools of marketing communication is Electronic Word of Mouth (eWOM). eWOM refers to any positive or negative reviews and statements made by potential and former customers about a product through the internet. From Figure 2 about eWOM Communication Patterns we can learn that the stimuli given by the communicator will affect the receiver of the communication. The receiver then gives an appropriate response according to what kind of stimuli that he or she has attained. In this case the eWOM will be the stimuliin the marketing communication activities. Herewith eWOM encourages consumers to share their experience and opinions of the products with other consumers. Word of mouth is known to be one of the most credible and trusted sources of marketing. Surveys and many studies proved that social media influencers are masters at eWOM. 


\section{B. Digital Influencer on YouTube}

Bandura [6], a social-science theorist wrote, "In the social learning system, new patterns of behavior can be obtained within direct experience or by observing the behaviors of others. This statement can help people understand why influencers are so "influential" [7].

Social media tools are becoming more valuable and one of the core elements of a communication strategy in an average consumer's life. According to [8], there are a wide range of factors that cause influencer marketing to become increasingly popular. These factors range from difficult-tomeasure criteria, such as "quality of content," to highly measureable factors including page views and search engine rank[7].

In this era YouTube has proven to be the desired social media platform by millenials. For social media influencers, YouTube becomes such a unique media platform as YouTube gives an influencer the opportunity to create and share videos that can make them get closer to the audiences and their lives[9]. For social media influencer's whose focus is on lifestyle branding, authenticity is key[7].

\section{Purchase Decision}

Purchase Decision or purchase intention is a planned behavior that a consumer willing to buy certain product[10]. There is a relationship between brand image and purchase intention[11]. Advertisement is a major factor to increase brand image on consumer, for that reason some companies use different kind of advertisements to attract customers[12]. Consumers who are influenced by advertisement shift their interests to the other brand which is advertised on the marketing tools[13]. There is a relation between attitude and purchase intention. Byoungho \& Yong [14] conveyed if the consumers have a positive attitude towards the brand it will increase purchase intention and actual purchase. Therefore, consumers who are satisfied with the product will have a positive attitude towards the brand and will make a repeat order or repurchase the product under the brand. The purpose of this study is to investigate the impact of a beauty vlogger to the purchase decision of the viewers.

Based on the theoretical review, the research outline is drawn on Figure 1, where the dimensions of each variables are stated and later elaborated into indicators which became the main foundation in making the questionnaire statements.

\section{METHODS}

The approach of this study is quantitative research. The analytical method includes library research and questionnaires. The researchers used a total quota sampling with non-probability sampling technique [15]. Data collection was done by distributing questionnaires to 100 respondents who were the viewers of video Wardah One Brand Makeup Tutorial and Review by Tasya Farasya. Tasya Farasya is one among the prominent beauty vloggers in Indonesia with subscribers as many as 1,248,063 and has $109,790,582$ viewers. Wardah is one of the popular brands among consumers. MarkPlus's research data in 2015 showed Wardah was ranked number one of the 10 most popular cosmetic brands in Indonesia with a percentage gain of $37.8 \%$. The tools used for processing the data was SPSS 22 version.

\section{RESULT AND DisCUSSION}

\section{A. Result}

The results of this study are as follows:

\section{1) Test of Validity}

From the computation the score of $r$ table is 0.361 , with significance value 0.05 . This means that all the items in the questionnaire are valid and can be tested to respondents.

\section{2) Test of Reliability}

Cronbach's Alpha value of both variables are as follows: $\mathrm{X}$ is 0.956 and $\mathrm{Y}$ variable is 0.951 . This means that the tool used in this study is reliable as the value score is more than 0.80 .

\section{3) Test of Normality}

From Kolmogorov-Smirnov column in the table 1, the significance value for both variables is 0.127 . Since $0.127>0.05$ this means that the data of both variables are normally distributed.

4) Test of Linearity

From the ANOVA Table, the significance value of linearity is 0.000 . If the value is less than 0.05 there is a linear interaction between $\mathrm{X}$ and $\mathrm{Y}$. This means that if there is a change in the value of eWOM variable (X), it will influence linearly to the value of Purchase decision variable (Y).

5) The Regression analysis can be explained as follows:

$$
\begin{aligned}
& Y^{\prime}=a+b X \\
& Y^{\prime}=-11.068+0.656 X
\end{aligned}
$$

a. The Constant value -11.068 ; it means that if the value of $\mathrm{X}$ (eWOM variable) is 0 , the value of $\mathrm{Y}$ (Purchase decision variable) is equal to -11.068 .

b. The Regression coefficient of X (eWOM variable) is 0.656 ; it means that if $\mathrm{X}$ (eWOM variable) is increased by 1 , the value of $\mathrm{Y}$ (Purchase decision variable) will raise by 0.656 . The coefficient is positive means that there is a positive relationship between X (eWOM variable) and Y (Purchase decision variable). The higher of $X$ value, the value of $\mathrm{Y}$ will increase accordingly.

\section{6) T Test (Test of Simple Linear regression coefficient)}

$\mathrm{T}$ Test is used to find out whether the independent variable is significantly impacted to the dependent variable.

$\mathrm{H}_{0}$ : There is not any influence of eWOM $(\mathrm{X})$ toward the purchase decision of Wardah Cosmetics (Y).

$\mathrm{H}_{1}$ : There is an influence of eWOM $(\mathrm{X})$ toward the purchase decision of Wardah Cosmetics (Y). 
The value of $\mathrm{t}$ is 26.362. That means that $\mathrm{t}$ value $>\mathrm{t}$ table $(26.362>1.983)$ so $\mathrm{H}_{0}$ is rejected. This study reveals that there is an is an influence of eWOM (X) toward the purchase intention of Wardah Cosmetics (Y).

\section{B. Discussion}

This research was conducted on the viewers of Wardah One Brand Makeup Tutorial and Review made by Tasya Farasya. The viewers were female with the aged of 20-35 years. The selection of this age range is because the age range belongs to the millennial generation category where they have high internet dependence. Internet consumption of millennial generation averages over 7 hours a day.

The results of the questionnaire showed that respondents were aged 24 years dominate with a percentage of $37 \%$. This shows that women less than 20 years of age have not been interested in using cosmetic products, while women over the age of 35 have no longer thought of using cosmetic products as the main thing. Women aged around 24 years dominate because this age is considered as the productive age for women and this condition direct them to have a higher need to support their appearance in the working place as well as in other activities.

Based on the education background of the respondents who were involved in this study, the data were dominated by $\mathrm{S} 1$ graduates as much as $59 \%$ and followed by D3 graduates as much as $32 \%$. This is because they mostly have already worked (employees) and every day they must apply some makeup to give a better impression of the more professional appearance. Respondents with high school education were only $6 \%$. Respondents with senior secondary education have more income low compared to respondents with D3, S1 and S2 education therefore they will save more on the use and purchase of cosmetic products. The use of cosmetic products is not every day but only at certain events such as parties and when gathering with friends. The last in the rank is S2 graduates as much as $3 \%$. The small number of respondents with $\mathrm{S} 2$ education is because they have no longer prioritized their appearance as they focus more on expanding career paths.

Based on the tabulation of data on each statement item, questionnaire item number 4 has the highest score that is equal to 394 with the statement "The resource person gives an honest review of cosmetic products". The statement is in the dimensions of the source credibility and indicators of trustworthiness. In the theoretical review, it is explained that understanding the credibility of EWOM's message source in the online world is very essential this means that statement number 4 confirms the theory, namely that Tasya Farasya as a communicator is considered honest and trustworthy in giving reviews about Wardah cosmetic products.

On the other hand, questionnaire item statement number 17 with the statement "I follow the sources on social media other than Youtube" has a score of 383 which illustrates that prospective customers want to get more information so that they follow other social media accounts owned by Tasya Farasya. In the six elements regarding the credibility of EWOM communicators, it is explained that one element includes social tie, namely the intensity level of social relations built by communicators and recipients.

The large number of respondents who followed Tasya Farasya on social media besides YouTube - such as Instagram, and Facebook - confirmed that on average the respondents wanted to have a social tie that was closer to Tasya Farasya because she was considered to be a credible communicator. For the purchase decision variable (Y) the highest score is in questionnaire item statement number 25 amounting to 375 , which is stated "I am looking for some information from various sources about Wardah cosmetic products". This result is in accordance with the theory put forward by Kotler \& Armstrong about the decision making process. Information seeking will be conducted if the respondent feels intrigued. The number of respondents who seek information about Wardah products proves that they have a high buying interest in Wardah products. Questionnaire item statement number 28 which says "Wardah is my first choice among various cosmetic brands" has the lowest score of 358. Respondents have other choices that they think are better so they do not make Wardah the first choice. Questionnaire item statement number 30 is "I decided to buy Wardah cosmetic products because there are many positive reviews about the product" have a score of 366 . The results are higher than the score of questionnaire item statement number 28. This shows that the respondents decided to buy Wardah cosmetic products because they were affected by the positive reviews but they have not made Wardah cosmetic products as the only brand they will buy. This is closely related to consumer loyalty. Millennials do tend to have a low level of loyalty to the brand. They are not reluctant to move to another brand if they feel that other brands are better able to provide benefits or benefits. In this case EWOM is an important factor in shaping consumer behavior. The recommendation or review presented by Tasya Farasya as someone who has tried Wardah products influence respondents' choices in making purchase decisions to buy Wardah products. But there are still some arguments about the millennial generation's loyalty on a certain brand as millennial generation tends to try new things and this will give some impacts to the brand loyalty. Suggestion for the future research is to reveal the impact of the digital influencer toward the brand loyalty of the millennial generation.

\section{CONCLUSION}

From the study, it can be concluded that Electronic word of mouth (EWOM) has a positive impact on Wardah cosmetic product purchasing decisions, with the value of 87.6\%. This shows that Tasya Farasya as beauty vlogger has an impact on her video viewers to buy Wardah cosmetic products, but if there are other better alternative products or brands, they will switch to other products that 
can provide more benefits. The practical implication of this study in industry is the producers of life-style products -including the cosmetic products- can collaborate with the beauty vloggers to advertise the products in order to acquire more customers. One thing that must be retained is the objectiveness of the review, since the beauty vloggers in this case of study are not in the same position as people who are endorsed by certain brand producers to advertise their products. The beauty vloggers should stay objectives in giving the reviews since the viewers might leave her if she only speaks on behalf of the producers. Finally, this study is theoretically oriented, it has surfaced, however, important issues for future research to consider the other platforms or channels used by digital influencers in conveying their messages in the form of reviews need to be further studied and analyzed.
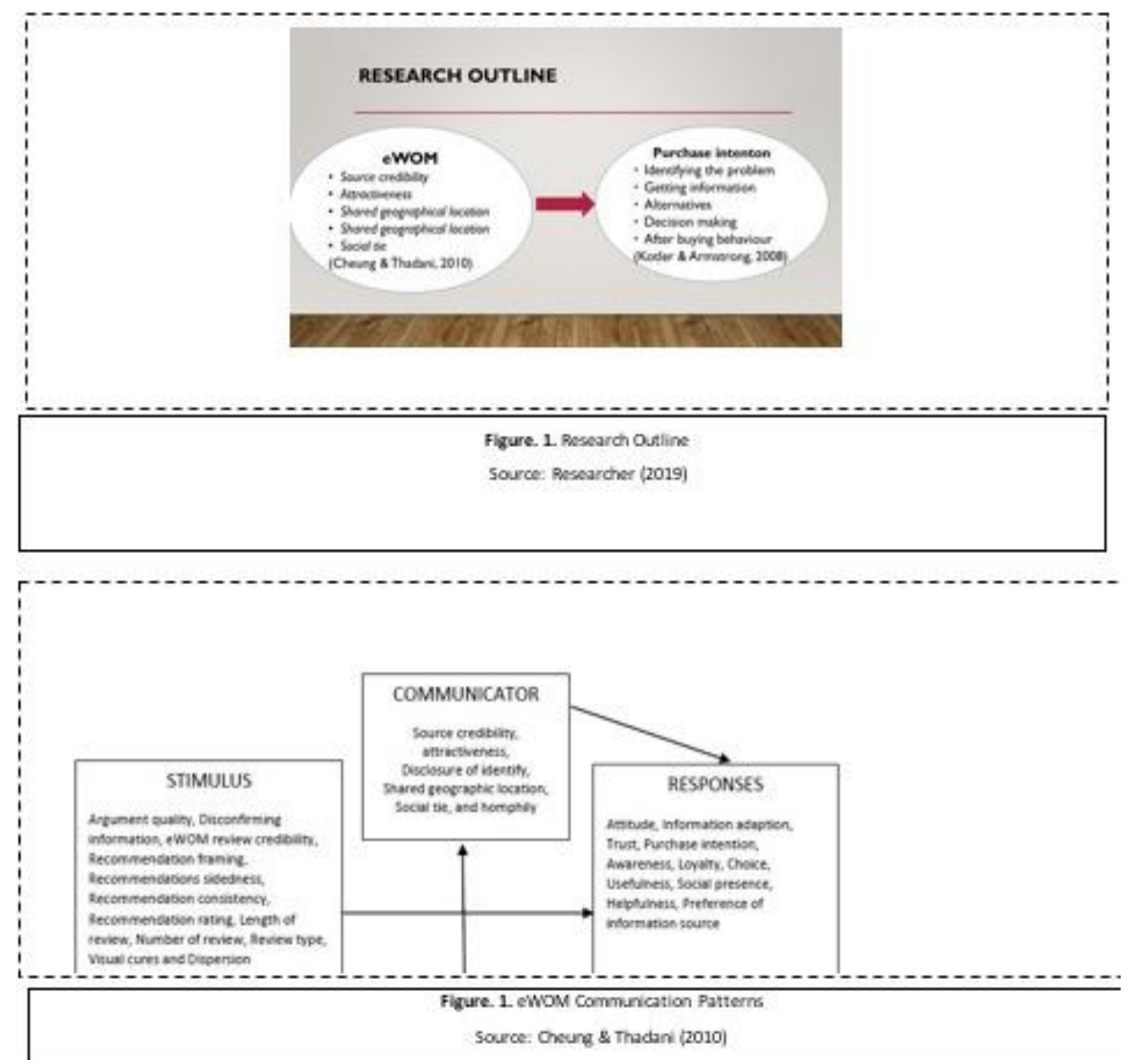

Figure 1. Research Outline and eWOM Communition Patterns[16]

\section{REFERENCES}

C. Fill and B. Jamieson, Marketing Communications. Edinburgh, UK: Edinburgh Business Schoo, 2006.

Kotler and Amstrong, "Principles of Marketing," 2010.

H. Alves, C. Fernandes, and M. Raposo, "Social media marketing: A literature review and implications," Psychol. Mark., vol. 33, no. 12, pp. 1029-1038, Dec. 2016.

C. Lin, Y.-S. Wu, and J.-C. V. Chen, "Electronic Word-ofMouth: The Moderating Roles of Product Involvement and Brand Image," in Diversity, Technology, and Innovation for Operational Competitiveness: Proceedings of the 2013 International Conference on Technology Innovation and Industrial Management, 2013.

[5] P. Kotler and K. L. Keller, Marketing Management, 14th ed. New Jersey: Prentice Hall, 2012.
[6] A. Bandura, Social Learning Theory. Englewood Cliffs, New Jersey: Prentice-Hall, 1977.

[7] M. Glucksman, "The rise of social media influencer marketing on lifestyle branding: A case study of lucie fink," Elon J. Undergrad. RTesearch Commun., vol. 8, no. 2, pp. 77-87, 2017.

[8] P. Gillin, "new media, new influencers and implications for the public relations profession," J. New Commun. Res., vol. 2, no. 2, pp. 1-10, 2008.

[9] M. Reza Jalilvand and N. Samiei, "The effect of electronic word of mouth on brand image and purchase intention," Mark. Intell. Plan., vol. 30, no. 4, pp. 460-476, Jun. 2012.

[10] T. J. Madden, P. S. Ellen, and I. Ajzen, "A comparison of the theory of planned behavior and the theory of reasoned action," Personal. Soc. Psychol. Bull., vol. 18, no. 1, pp. 3-9, Feb. 1992.

[11] R.-H. Dorota, "Determinants of consumer purchasing behaviour," Management, vol. 17, no. 1, pp. 333-345, 2013. 
[12] K. C. Manning and D. E. Sprott, "Multiple unit price promotions and their effects on quantity purchase intentions," $J$. Retail., vol. 83, no. 4, pp. 411-421, Dec. 2007.

[13] M. I. Tariq, M. R. Nawaz, M. M. Nawaz, and H. A. Butt, "Customer perceptions about branding and purchase intention: A study of FMCG in an emerging market," J. Basic Appl. Sci. Res., vol. 3, no. 2, pp. 340-347, 2013.

[14] B. Jin and Y. Gu Suh, "Integrating effect of consumer perception factors in predicting private brand purchase in a
Korean discount store context," J. Consum. Mark., vol. 22, no. 2, pp. 62-71, Mar. 2005.

[15] Sugiyono, Metode Penelitian Kuantitatif Kualitatif dan $R \& D$. Bandung: Alfabeta, 2010.

[16] C. M. Cheung and D. R. Thadani, "The effectiveness of electronic word of mouth communication: a lyterature analysis," in 23rd Bled eConference eTrust: Implications for the Individual, Enterprises and Society, 2010, vol. 18, pp. 329-345. 